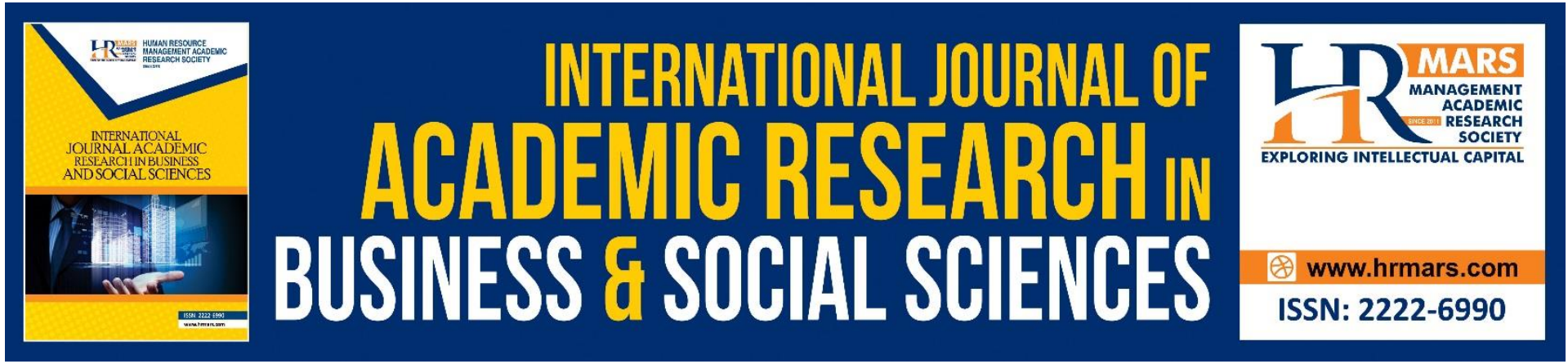

\title{
Polyethene: The Exploration and Experimentation Extrinsic Property of the Material in Environmental Concern in Aesthetic Process
}

Faiz Mohamed Yunus, Ramlan Abdullah

To Link this Article: http://dx.doi.org/10.6007/IJARBSS/v11-i9/11111

DOI:10.6007/IJARBSS/v11-i9/11111

Received: 20 July 2021, Revised: 31 August 2021, Accepted: 10 August 2021

Published Online: 22 September 2021

In-Text Citation: (Yunus \& Abdullah, 2021)

To Cite this Article: Yunus, F. M., \& Abdullah, R. (2021). Polyethene: The Exploration and Experimentation Extrinsic Property of the Material in Environmental Concern in Aesthetic Process. International Journal of Academic Research in Business and Social Sciences, 11(9), 1169-1176.

Copyright: (c) 2021 The Author(s)

Published by Human Resource Management Academic Research Society (www.hrmars.com)

This article is published under the Creative Commons Attribution (CC BY 4.0) license. Anyone may reproduce, distribute, translate and create derivative works of this article (for both commercial and non-commercial purposes), subject to full attribution to the original publication and authors. The full terms of this license may be seen at: http://creativecommons.org/licences/by/4.0/legalcode

Vol. 11, No. 9, 2021, Pg. 1169 - 1176

http://hrmars.com/index.php/pages/detail/IJARBSS

JOURNAL HOMEPAGE

Full Terms \& Conditions of access and use can be found at http://hrmars.com/index.php/pages/detail/publication-ethics 


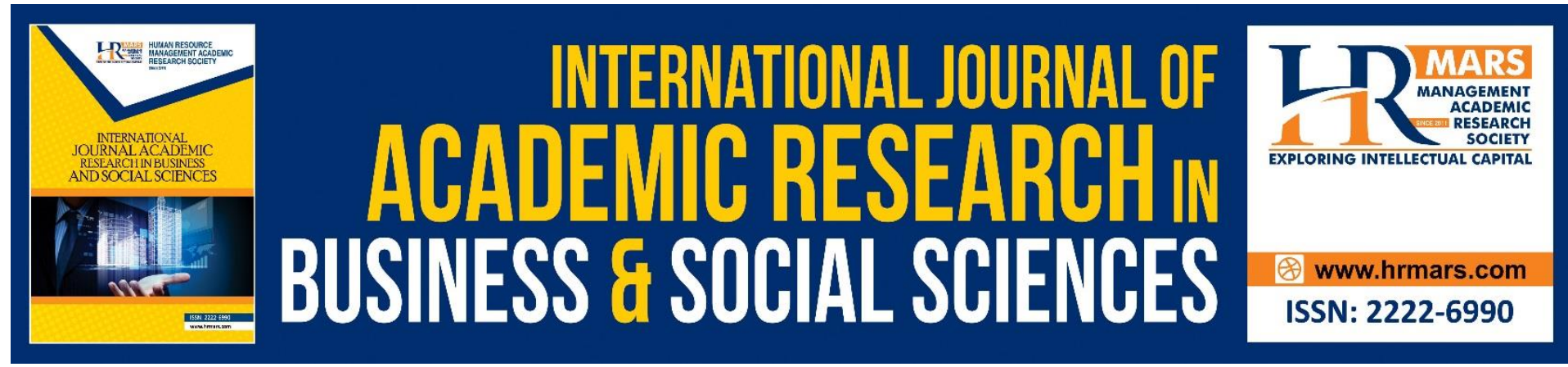

\title{
Polyethene: The Exploration and Experimentation Extrinsic Property of the Material in Environmental Concern in Aesthetic Process
}

\author{
Faiz Mohamed Yunus, Ramlan Abdullah \\ Department of Fine Art, Faculty of Art \& Design Universiti Teknologi MARA \\ Shah Alam 40450 Selangor \\ Email: ramla278@uitm.edu.my
}

\begin{abstract}
This research will look at the phenomenology and process of artistic production. In contemporary art, exploring the art of sculpture requires experience, specialised techniques, and flexible materials. Welding techniques were investigated as a starting point for this body of work. In my studio practice, the process began by examining the process of sculpturemaking in order to find a way to express my obsessions through art. As my research progressed, the project developed an interest in the encountered techniques, including welding, glueing, moulding, casting, and colouring. My work became increasingly concerned with documentation and methodology.
\end{abstract}

Keywords: Minimalism, Exploration, Formation, Conversation, Phenomenology, Surface Energy, Constructive.

\section{Introduction}

Art is created to evaluate the needs and record events, ideas, and feelings in the past or present to be a source of learning and knowledge about the lives of the artists. They used art then, and we use it today for personal, social, spiritual, and educational functions. Contemporary is any if not all art that is produced today. It cannot be generalised like the past movement as it is contemporaneous. It is not to say that it is only about the presentation of the present, but rather about the phenomenon of how art has become so widely available in comparison to the past and the reactions to it (Smith, 2009). In the creative world, practice is the basis of a research project where studio documentation is the main way to gain knowledge and understanding about art and the experiment on material and medium the artists used. Artist/designer is viewed as a researcher who examines the value of artistic process/design process as the production of new knowledge (Barret \& Bolt, 2010, p. 6). In that sense, the artist's use of materials and media depends on understanding ideas and concepts to be communicated. Practice-led research/practice-based research/studio-based research refers to those research projects in which creative practice plays a primal role in the cluster of research methods used (Freitas, 2002). Her study realizes the importance of studio documentation as a common practice among artists. The documentation from the artist that 
proved the work of art was the result of the investigation and the removal of the artist itself against their work.

\section{Method}

From finding the right materials to making sculptures, I needed a place to work. Initially, the idea of making work started with the subject matter and story content for the work. I realized that I am good with materials and creating artwork just shapes without regard for meaning and storytelling. At first, I thought of producing something that required a specific purpose. I began experimenting with the material, exploring the capacity of the material to change and see the effect on the plastic surface. I prefer to create a minimal and straightforward form.

At the beginning of my work, I was more concerned with the correct shape to build. I concentrated on the same shape when I was active in the exhibition. I create knotted, twisted, or swirl/rotating conditions. As a result, the finished product of my artworks resembles more of those forms. These include forms like concave rope, twisted and tied roots, and so on. I started by making a model using plaster of Paris (POP), using the most common form I used, the ' $L$ ' pipe. With this mould, I can create the shape I want. The use of plastic fragments to create the sculpture is used in the mould, and the heating process is carried out in the mould.

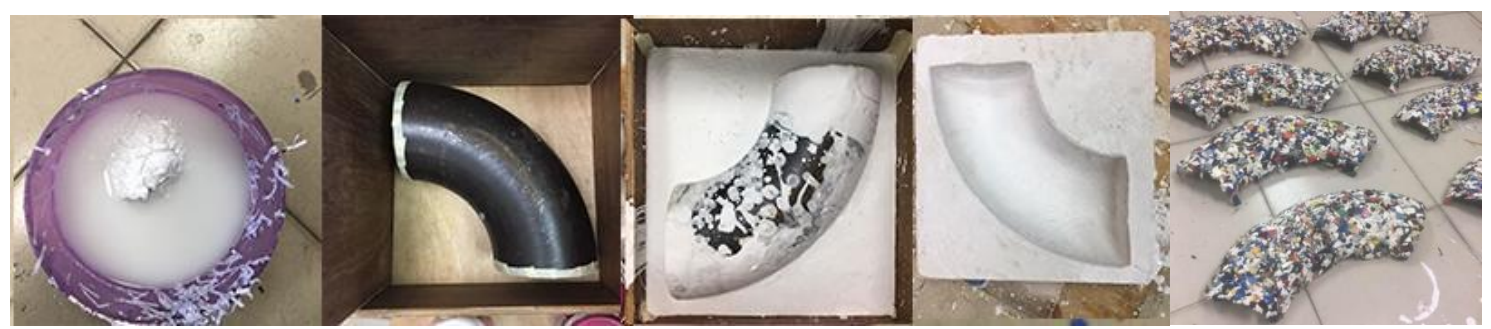

Fig.1: The process of moulding (preparation for POP and model) and the heating process.

The result from heating the plastic pieces inside the mould, and from here, I constructed each one to make the artwork (Fig. 1). It is complicated to create this shape, from moulding to the recycling of plastic pieces and the desired shape, making me wonder if this is what I am using and does this form have enough impact on the results of this work? After a discussion and looking back on the uniqueness of this plastic material, I became more interested in the aesthetic value of the material. The resulting braiding effect and unique repetition of the shape made me more focused on the minimal form. The minimal shape using complex materials was enough for me to experiment and explore the material. So, I decided to create a simple and easy shape that would not interfere with the aesthetic value of the plastic material I was using. 


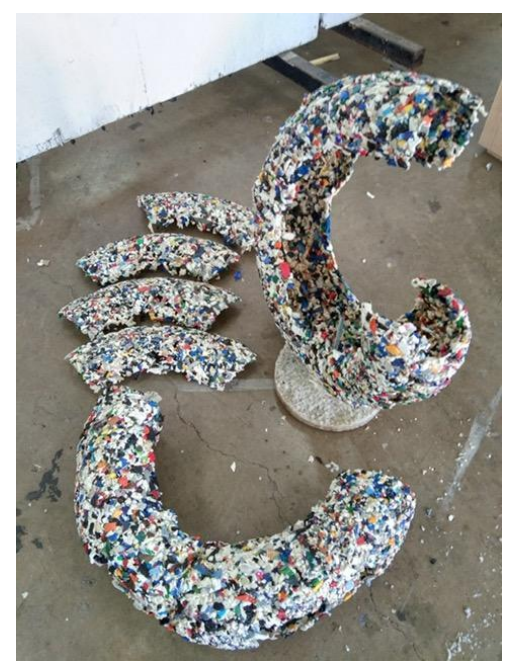

Fig.2: The constructive plastic fragments into works.

To maintain the uniqueness of the textures, I focused on simple and easy shapes like the work of minimalist artists Carl Andre, Frank Stella, and Donald Judd. Rearranging or constructing plastic fragments into complex shapes or materials and minimally assembling them became my motivation. Fig. 2 shows the shape glueing together. One question stood out during this process: Will I remove away the shape or maintain the shape? Quite frankly, I am more focused on exploring materials that can be transformed into unique and dynamic.
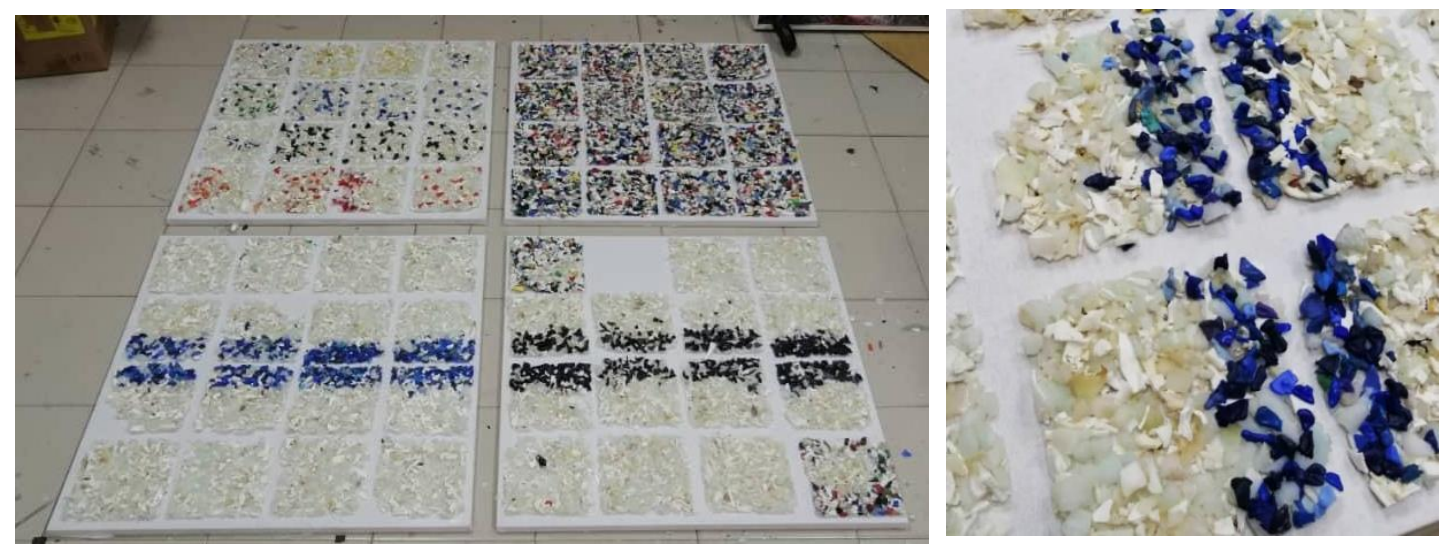

Fig. 3: Polyethylene after heating

Polythene will melt and attach when heated, but it will break if we press hard on it. I took the initiative to re-seal using resin. This method is a natural way to prevent debris from being removed. In Fig.3, as a result of applying heat using a blower on the pieces of plastic, it became firmly attached. I separated the colours into blue, black, red, and yellow to distinguish between them. Single-layer for plastic is very thin and adheres perfectly. This experiment focused on the thin layer first to see the effect of plastic melting on each other. High patience and technical prudence are essential to ensure the desired results. Although the yield is very subjective, I think the resulting aesthetic value significantly impacts the resulting surface. 


\section{Results and Discussion}

To help counter the COVID-19 pandemic, the government of Malaysia initiated the Movement Control Order (MCO), effective on 18 March 2020, to increase social distancing and slow down the transmission rate of the virus. The MCO order was extended three times, each for another two weeks, until 12 May 2020. On 13 May, Malaysia moved into the Conditional Movement Control Order (CMCO). On 8 June, Malaysia moved into the Recovery Movement Control Order (RMCO) (Council, 2020). The MCO began on $18^{\text {th }}$ March 2020; Malaysia received a COVID-19 pandemic until 31st July 2020, phase by phase, which forced me to do all the work at home because I could not leave the house. I am very grateful for the materials I have and the simple techniques for making this sculpture. From welding to heating, from steel to plastic. I can easily bring the material back home because they are light and easy to handle.

When I was isolated in my home, I started looking for a suitable mould for my next idea. I was more focused on simple tools that are already in my house. Plastic fragments were placed in a pan, and heating is done using a blower. The curved surface of the pan creates a unique work. I repeated it over and over again to get the desired result. I separated them into colours, then comes the first and place them in the pan according to the colour. The COVID19 pandemic has had a huge impact on the production of this work. I had to look through household appliances to get this done.

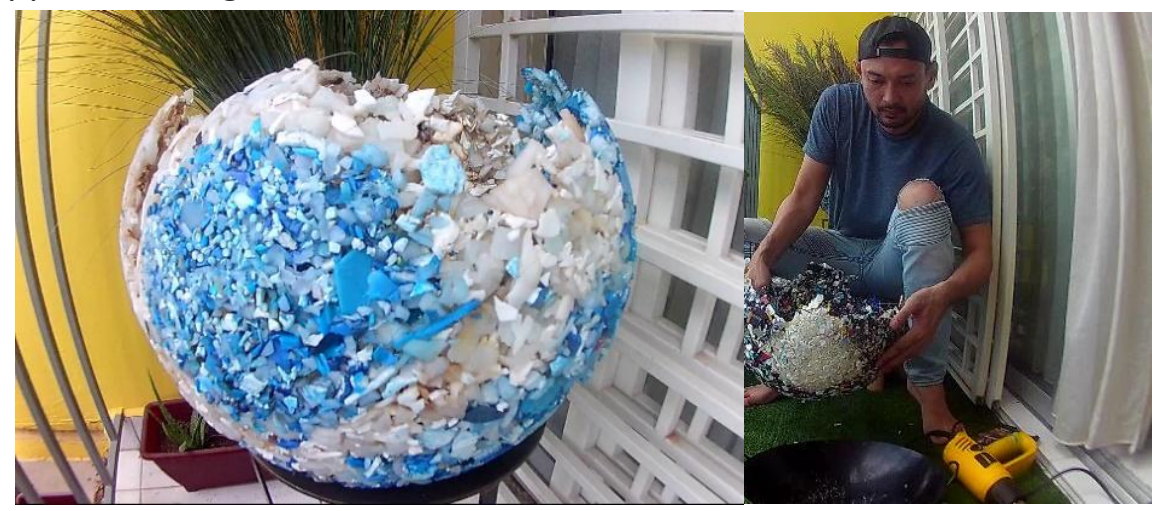

Fig.4: Working place

Fig.4 shows where I did my work when the MCO took place. With such a small space, I managed to make the work because of the ease and convenience of materials. Before the $\mathrm{MCO}, \mathrm{I}$ had collected this waste plastic or discarded material first. But the creation of artwork will be limited by the lack of supply, nor can I go out to seek inspiration. I just have to use what is in my house only. I made a lot of sketches and chose the ones that fit the MCO situation. As a result of the curved shape of the pan, I created a ball or shape of the sphere. Polyethylene is the most popular plastic in the world. The polymer makes grocery bags, shampoo bottles, paint caps, children's toys, and even bulletproof vests. For such a versatile material, it has a straightforward structure, the simplest of all commercial polymers. I think I have chosen the suitable material, and I understand how to solve the problems that will come up when preparing the work. In addition to the burning process to attach the plastic fragments, I used resin to secure them. You can create works of art that enchant with their clarity, luminosity, brilliance, and depth with resin. Resin casting is a method of plastic casting where a mould is filled with a liquid synthetic resin, which then hardens. It is primarily used for small-scale production like industrial prototypes and dentistry. It can be done by amateur hobbyists with little initial investment and is used to produce collectable toys, 
models, figures, and small-scale jewellery production. So, in my case. I need to use resin to strengthen the effect of the plastic blend.
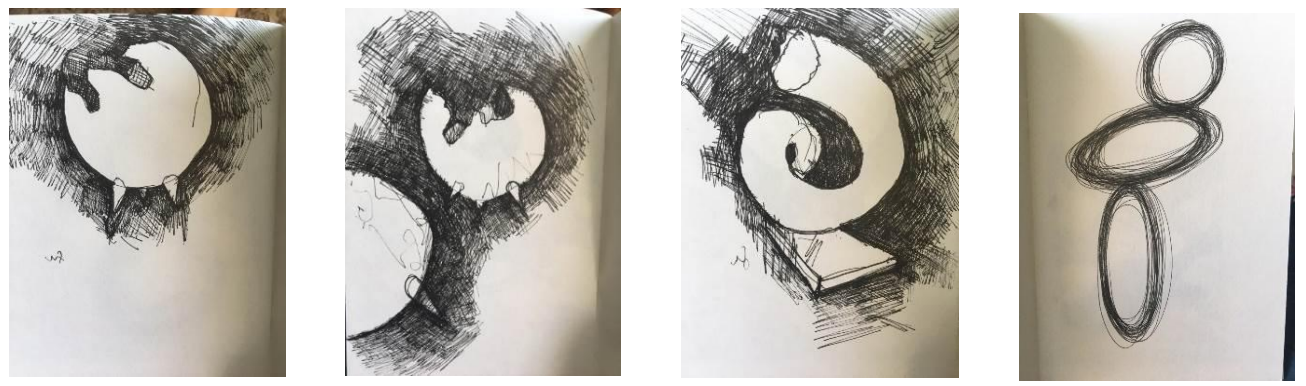

Fig. 5: The sketches to expand and develop the idea.

Materials and place influence my sketches in Fig. 5; what I do depends on what I have. Items are minimal, and I have to anticipate what will happen. In the production of my work, I take only real action-no need to think about hardships like welding, cutting wood, or working hard. I just have to create the work by following the existing mould.
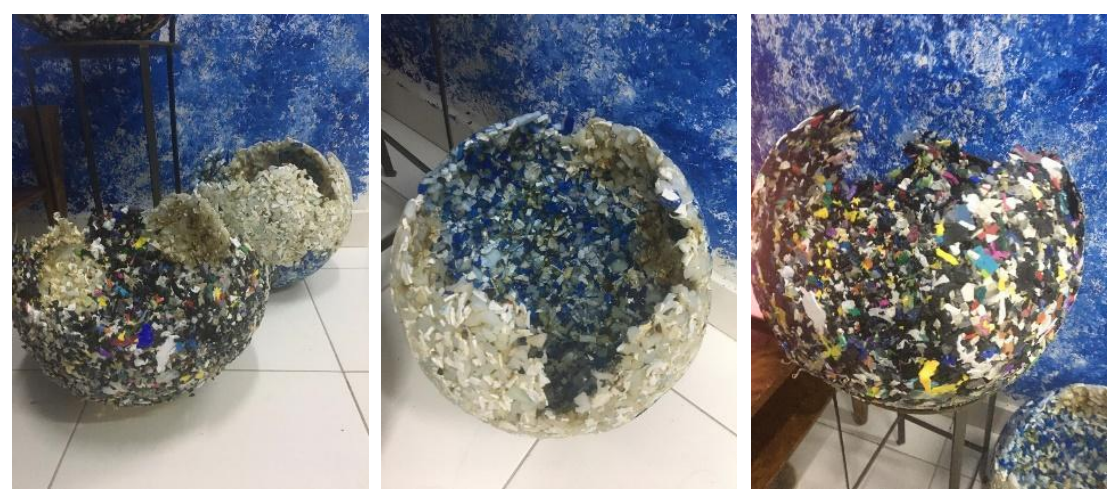

Fig.6: Colours are separated to get different effects

While working during this MCO, I could not afford to make a more significant piece. But the original idea of just wanting the aesthetics of the process had a considerable impact on this work. The factory that supplied the plastic to me temporarily closed its factory due to the COVID-19 pandemic. After the MCO, I still could not go to the studio at UiTM Jalan Othman to continue the experimentation and exploration of plastic. I knew I just need to make simple shapes. I cooked the plastic pieces in the mould and let them melt using my kitchen stove. This time I burned in large quantities, and the plastic became thicker and more robust. As shown in Fig.7, the plastic pieces become like marble and produce exciting colours. 


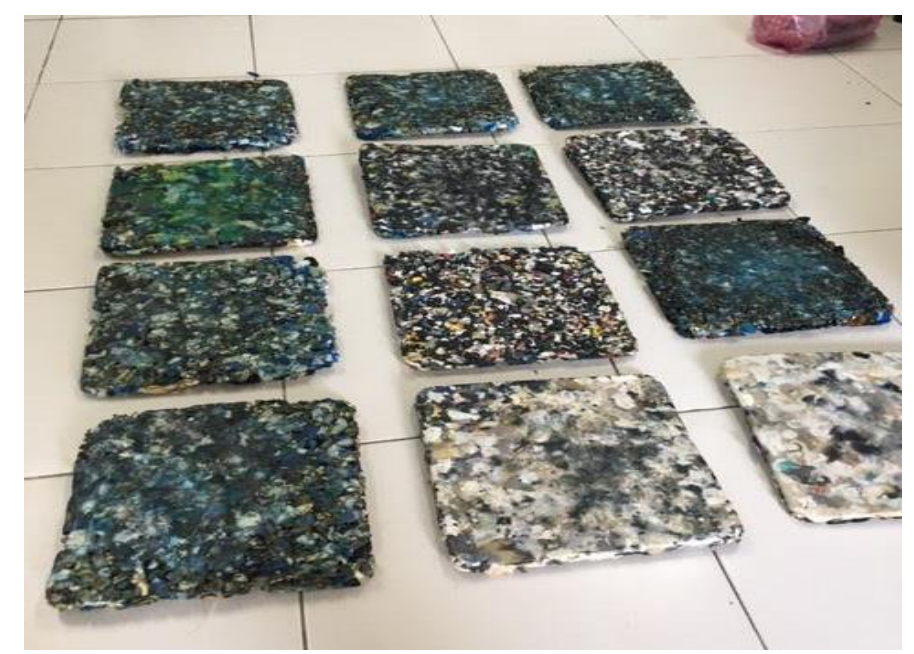

Fig.7: Square shapes from plastic of multiple colours.

Producing a work should have preliminary planning, the following action, and the possibilities that will happen to be aspects in preparing the work. Providing an initial sketch of how to hang the work is very important. To produce art from this plastic material, my research is like a scientist, evaluating, understanding, experimenting, identifying materials, and so on. But I still think the resulting artwork is part of my understanding of the material. What else can this plastic do? This aesthetic process makes this plastic product more appreciated and has an extraordinary impact on me. From the heating and combustion practices I did, I understood the properties of plastic in more depth. Thermoplastic and thermosets are plastic fragments that can melt quickly if heated and harden if cold water is placed on them. At the same time, plastic thermosets are difficult to dissolve and require appropriate techniques to form them. I feel fortunate after the factories are given space to operate again. I can get these plastic sheet materials back quickly and simply. After seeing the final product of crushing plastic, I was interested in the white or crystal colour that results from cleaning from the shower.

\section{Conclusion}

In conclusion, the real progress through the art-making process and developing ideas through the studio process. The studio documentation and exploring the phenomenology of art practice by materials of polyethene or polymer using heating, burning and glueing by resin as a technique. The artwork has made mature progress in producing a series of artworks. Using some research objectives and research questions that I want to achieve helped me deal with the problem of preparing and completing works in the right way. Along with the practice of understanding the nature of plastic, I never thought it could be achieved up to this point, helping me strengthen pedagogy in my research. It all starts with patience and knowledge of how to deal with suppliers. By supporting the experience of working with industry and terms in the context of my practice, my idea of exploring the phenomenology of the art-making process became magical and developed effectively.

\section{Acknowledgements}

The authors gratefully acknowledge this artistic research publication was support under the UiTM grant (600RMC/DANA5/3/BESTARI(TD)(001/2020). 


\section{References}

Artnet Auctions. (n.d.). Retrieved from http://www.artnet.com/artists/arin-dwihartantosunaryo/

Asia Contemporary Art Buyer. (n.d.). Retrieved from https://www.asiacontemporaryart.com/artists/dir_attachments/2130_0.pdf

Barret, E., \& Bolt, B. (2010). Practice as Research, Approaches to Creative Arts Enquiry. London, New York: I.B Tauris \& Co.Ltd.

Ciclitira, S. (2014). In Malaysian Eye, Contemporary Art (pp. 50-51). Milano, Italy: Skira Editore S.p.A. Palazzo Casati Stampa.

Ciclitira, S. (2014). In Malaysian Eye, Contemporary Malaysian Art (pp. 226-227). Milano, Italy: Skira Editore S.p.A, Palazzo Casati Stampa.

Ciclitira, S. (2014). In Malaysian Eye, Contemporary Malaysian Art (p. 310). Milano, Italy: Skira Editore S.p.A. Palazzo Casati Stampa.

Council, M. D. (2020). MCO Updates. Retrieved from https://www.mdbc.com.my/mco-updates/

Feldman, E. B. (1994). Practical art criticism. Englewood Cliffs, N.J.: Prentice Hall.

Freitas, N. (2002). Documentation of Studio Practice.

Gallery, M. (2012). Monash University. Retrieved from https://www.monash.edu/mada/galleries/madagallery/exhibitions/older/older/2012/hanif-khairi,-arcabudaya-expression-andtransformation

Gallery, S. (2018, May 08). Saradise Gallery. Retrieved from http://www.saradise.my/saradise-gallery/featured-artists/mohd-razif-bin-mohdrathi/

Hamid, M. J. (2008). Apresiasi \& Kritikan Seni Visual. Tanjong Malim: Universiti Pendidikan Sultan Idris.

Honour, H., \& Fleming, J. (2009). A World History of Art. London: Laurence King Publishing Ltd.

ITSLIQUID. (2017). Carl Andre; Sculpture as Place, 1958-2010. Retrieved from https://www.itsliquid.com/carl-andre-sculpture-as-place-1958-2010.html

Khan, Z. (n.d.). Abdul Muthalib Musa. Retrieved from Core Design Gallery: http://malaysiacontemporaryart.coredesigngallery.com/2013/09/abdul-multhalibmusa/

Malaysia and Combodia. (n.d.). Retrieved from http://malaysiaandcambodia.blogspot.com/2012/11/111-dataran-pahlawan-heroessquare.html

Mech4study. (2016). Retrieved from https://www.mech4study.com/2016/02/types-of-rivets-joints.html

Mills, C. (n.d.). Negating Art's Ontology: Minimalism and Phenomenology. Retrieved from https://www.academia.edu/17429793/Negating_Arts_Ontology_Minimalism_and_P henomenology?email_work_card=view-paper

Ragan, R. (2000). Glencoe Art talk. United States of America: Glencoe/McGraw-Hill.

Ragans, R. (2000). In Glencoe ArtTalk (pp. 98-99). United States of America: Glencoe/McGraw-Hill.

Smith, T. (2009). What is Contemporary Art? Chicago: University of Chicago Press. Visual Art Gallery. (2002). The Young Contemporaries Artist. The Young Contemporaries Artist. 